\title{
Desiccation survival capacities of two invasive crayfish species
}

\author{
F. Banha( ${ }^{(1), \star}$, P.M. Anastácio ${ }^{(1)}$ \\ Received June 25, 2013 \\ Revised October 21, 2013 \\ Accepted October 24, 2013
}

Key-words:

Pacifastacus

leniusculus,

Procambarus

clarkii,

desiccation

survival, invasive species, dispersal

\section{ABSTRACT}

The signal crayfish, $P$. leniusculus and the red swamp crayfish, $P$. clarkii are two invasive crayfish species with widely world distribution, being both present at Iberian Peninsula. In this work we study the desiccation survival capacities of both species at $24^{\circ} \mathrm{C}$. Our results showed that both species are capable of surviving exposure to air for long periods of time, with an $\mathrm{LT}_{90}$ of 17.6 and $21.5 \mathrm{~h}$, respectively, for red swamp crayfish and signal crayfish. Our findings are in accordance with the great overland dispersal capacities attributed to these crayfish species.

\section{RÉSUMÉ}

\section{Capacités de survie à la dessiccation des deux espèces d'écrevisses invasives}

\author{
Mots-clés : \\ Pacifastacus \\ leniusculus, \\ Procambarus \\ clarkii, \\ survie à la \\ dessiccation, \\ espèces \\ envahissantes, \\ dispersion
}

\begin{abstract}
L'écrevisse signal, Pacifastacus leniusculus et l'écrevisse rouge des marais, Procambarus clarkii sont deux espèces d'écrevisses exotiques avec une distribution mondiale, toutes deux présentes dans la péninsule ibérique. Dans ce travail, nous étudions la capacité de survie à la dessiccation de $P$. clarkii à $24^{\circ} \mathrm{C}$ et $30 \%$ d'humidité relative et de $P$. leniusculus également à $24^{\circ} \mathrm{C}$, mais à une humidité relative de $50 \%$. Nos résultats ont montré que les deux espèces sont capables de survivre à l'exposition à l'air pendant de longues périodes de temps, avec une $\mathrm{LT}_{90}$ de 17,6 et 21,5 h pour l'écrevisse rouge des marais et l'écrevisse signal, respectivement. Nos résultats sont en accord avec les grandes capacités de dispersion par voie terrestre attribuées à ces espèces d'écrevisse.
\end{abstract}

Crayfish are one of the most commonly introduced freshwater organisms and are responsible for declines and extinctions of native species throughout the world (Guan and Wiles, 1997; Lodge et al., 1998, 2000; Nyström et al., 2001, Westman et al., 2002). The signal crayfish Pacifastacus leniusculus (Dana, 1852) and the red swamp crayfish, Procambarus clarkii (Girard, 1852) are two North America native crayfish species with worldwide distribution due to their economic importance, but also due to their high dispersal abilities, fast growing populations and wide niches (Hobbs et al., 1989). Severe negative impacts on invaded areas are attributed to these two crayfish species, such as competition with native species (Nyström, 1999), dissemination of the crayfish plague (Diéguez-Uribeondo et al., 1997), habitat and ecosystem changes (Geiger et al., 2005), negative effects on amphibian populations (Nyström, 1999;

(1) IMAR - Centro de Mar e Ambiente / Departamento de Paisagem, Ambiente e Ordenamento, Universidade de Évora, Rua Romão Ramalho, $n^{\circ}$ 59, 7000-671 Évora, Portugal

* Corresponding author: filipebanha@hotmail.com 
Cruz et al. , 2008) and losses on economic activities such as rice production (Anastácio et al., 2005). In the Iberian Peninsula these two crayfish were first introduced into Spain nearly at the same time, $P$. clarkii in 1973 and $P$. leniusculus in 1974 respectively, for aquaculture purposes (Diéguez-Uribeondo et al., 1997; Alonso et al., 2000). In Portugal, the fist records of these species were in 1979 for $P$. clarkii in the Caia river (Ramos and Pereira, 1981) and in 1997 for P. leniusculus at the river Maçãs (Bernardo et al., 2001). Currently these species have a wider distribution, with $P$. clarkii being present across all the Iberian Peninsula, and $P$. leniusculus having a more restricted distribution. The present distribution of these species reflects their high dispersal capabilities, high population growth rates and wide niches, which makes them very successful invaders (Hobbs et al., 1989) but also years of successive illegal translocations (Alonso et al., 2000; Diéguez-Uribeondo, 2006).

The desiccation survival capacities of aquatic species are intrinsically related with their passive dispersal capacities (Figuerola and Green, 2002), but also with their active dispersal capacities on dry land (Correia and Ferreira, 1995; Cruz and Rebelo, 2007). In this work, we assess the desiccation survival capacities of $P$. clarkii and $P$. leniusculus.

Red swamp and Signal crayfish were collected using baited traps, respectively in the Di$\operatorname{vor}\left(38^{\circ} 52^{\prime} 56.58^{\prime \prime} \mathrm{N} ; 8^{\circ} 10^{\prime} .21 .84^{\prime \prime} \mathrm{W}\right)$ and the Maçãs rivers $\left(41^{\circ} 40^{\prime} 36.00^{\prime \prime} \mathrm{N} ; 6^{\circ} 38.06 .00^{\prime \prime} \mathrm{W}\right)$. Specimens of both species were separately acclimated during 5 days in aerated plastic containers $(60 \times 40 \times 40 \mathrm{~cm})$ with dechlorinated tap water at an 12:12 h light:dark cycle and carrots were fed to both species. We performed two separate laboratory experiments to check how long each of these two invasive crayfish could survive out of water, under controlled conditions at $24{ }^{\circ} \mathrm{C}$. This temperature was chosen because it falls on the top of the range for the annual average maximum temperatures in the Iberian Peninsula (Ninyerola et al., 2005). Eighty-one red swamp crayfish (cephalotorax length $=44.36 \mathrm{~mm} \pm 4.53 \mathrm{SD}$; weight $=19.38 \mathrm{~g} \pm 6.63 \mathrm{SD}$; Fulton index $=0.23 \pm 0.03 \mathrm{SD}$ ) and Signal crayfish (cephalotorax length $=37.88 \mathrm{~mm} \pm \mathrm{SD}$; weight $=16.64 \mathrm{~g} \pm 7.90 \mathrm{SD}$; Fulton index $=0.29 \pm 0.08 \mathrm{SD}$ ) were distributed into 9 groups of 9 individuals for each species. Each crayfish was individually placed into a plastic box $(20 \times 20 \mathrm{~cm})$ and the boxes were kept at $24{ }^{\circ} \mathrm{C}$ with a relative humidity $(\mathrm{RH})$ of $30 \%$ and $50 \%$ for the experiments with the red swamp crayfish and the signal crayfish respectively. The experiments lasted $27 \mathrm{~h}$ and every $3 \mathrm{~h}$, the number of crayfish alive in one randomly selected group was checked. Crayfish were considered alive if we could detect movement of pereiopods, antenulles or maxillipeds. This procedure started by visually searching, during $30 \mathrm{~s}$, for the presence of movement. If no movement was detected the individual was removed manually from the box, holding it by the pleon on an "upside down" position. Under these circumstances, many of the alive crayfish presented a reflex movement of pleon, if they did not we would then watch more closely for vestigial movement of pereiopods, antenulles or maxillipeds. Also, alive individuals in this position presented the pereiopods flexed and dead ones presented all pereiopods downturned by gravity. Statistical analyses were performed using IBM SPSS Statistics 20.

Our results show that both species presented no mortality until a period of $3 \mathrm{~h}$ out of water Red swamp crayfish started to die after 6 h of desiccation (Figure 1) but signal crayfish only started to die at $9 \mathrm{~h}$ (Figure 2). The number of crayfish alive was registered for a maximum of 18 and $21 \mathrm{~h}$ for red swamp and signal crayfish, respectively. Probit analysis indicated for red swamp crayfish an $\mathrm{LT}_{50}$ of $11.9 \mathrm{~h}(95 \%$ C.L. $=9.9-13.7)$ and an $\mathrm{LT}_{90}$ of $17.6 \mathrm{~h}(95 \%$ C.L. = 15.4-21.6) (Figure 1). The statistical model fitted adequately our observed data (Pearson goodness-of-fit test: $\left.X^{2}=1.289, d . f=8, P=0.996\right)$. For signal crayfish a probit analysis indicated an $\mathrm{LT}_{50}$ of $15.8 \mathrm{~h}(95 \%$ C.L. $=13.9-17.7)$ and an $\mathrm{LT}_{90}$ of $21.5 \mathrm{~h}(95 \% \mathrm{C} . \mathrm{L} .=$ 19.2-25.6) (Figure 2). The statistical model also fitted adequately our observed data (Pearson goodness-of-fit test: $X^{2}=1.661$, d.f. $=8, P=0.990$ ).

Our study shows that both $P$. clarkii and $P$. leniusculus can survive out of water easily more than $10 \mathrm{~h}$ in severe conditions, which are typical of the lberian summer. Although our findings show an apparent higher desiccation survival capacity of $P$. leniusculus face to the $P$. clarkii, the observed differences may simply reflect different conditions, namely the higher relative humidity (almost the double) during the $P$. leniusculus experiment. Under similar conditions, 


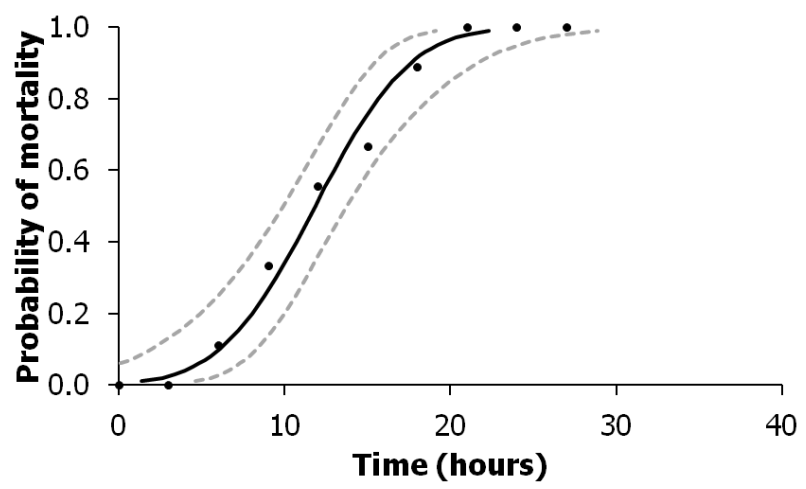

Figure 1

Probability of $P$. clarkii mortality as a function of the time spent out of water at $24{ }^{\circ} \mathrm{C}$ and $30 \%$ relative humidity. The black dots are the observed proportions of dead P. clarkii; the black line was obtained by Probit analysis, with the respective 95\% confidence intervals (dotted line).

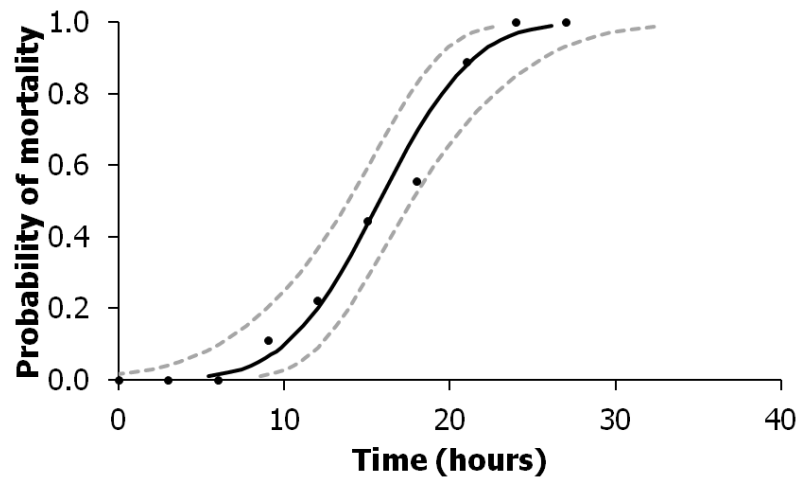

\section{Figure 2}

Probability of $P$. leniusculus mortality as a function of the time spent out of water at $24{ }^{\circ} \mathrm{C}$ and $50 \%$ Relative humidity. The black dots are the observed proportions of dead P. leniusculus; the black line was obtained by Probit analysis, with the respective 95\% confidence intervals (dotted line).

namely of temperature, other exotic freshwater crustaceans with a wide distribution across Europe, the Mediterranean river shrimp, Athyaephyra desmarestii (Banha and Anastácio, 2012) and the North American amphipod, Crangonyx pseudogracilis (Rachalewski, 2013) presented a survival capacity approximate 10 times lower than the presently studied species. These findings have several implications for the dispersal of these crayfish species both by active and passive means, including Human mediated transport. For active dispersal, namely walking over dry land, a great capacity to survive out of water means a great capacity to cover large distances out of their natural environment. According to Pond (1975) the white-clawed crayfish (Austropotamobius pallipes), a native European crayfish species, presented a mean walking speed on dry land of $54 \mathrm{~m} / \mathrm{h}$, so in $10 \mathrm{~h}$ a crayfish would walk $540 \mathrm{~m}$. For P. clarkii the maximum observed walking speed on dry land was of $90 \mathrm{~m} / \mathrm{h}$ (Ramalho, 2012) although the mean values are lower. Taken our results for this species, namely the $L T_{90}$ value, the maximum distance for active dispersal on dry land would be of approximately $1.6 \mathrm{~km}$ if walking continuously and always heading in one direction. This distance is enough to surmount natural or Human-made barriers on a stream, but also, under drought situations, it allows crayfish to escape from a drying pool and reach a more permanent water body. So, the desiccation survival capacities of $P$. clarkii and $P$. leniusculus are important features that can explain their great dispersal capacities. Our findings have also implications for passive dispersal, namely Human translocations; it is known that crayfish introductions and translocations that allowed many crayfish species to invade large geographic areas are due to illegal bucket transport by fishermen (Holdich et al., 2009; Lodge et al., 2000; Taylor 2000; Souty-Grosset et al., 2006). For a fisherman, the transport of crayfish specimens out of water is simpler and involves less 
equipment, but it also allows the transport of more individuals from one point to another. Therefore according to our results on the survival capacities of $P$. clarkii and $P$. leniusculus, both species can be easily transported for long distances in a small bucket or a cloth bag, undetected by the authorities. The distances involved in this process can easily overcome river basins, separated by dozens of kilometers if a car is involved. In conclusion, any management actions directed to these invasive species should take into account the great desiccation survival capacity of these invasive crayfish species.

\section{ACKNOWLEDGEMENTS}

This study was partially financed by FEDER funds through the "Programa Operacional de Factores de Competitividade - COMPETE" and by national funds through "FCT - Fundação para a Ciência e Tecnologia" on the scope of the project DID (Dispersal of Invasive Decapoda) (PTDC/BIABEC/105182/2008). F. Banha holds a PhD grant from FCT (SFRH/BD/81378/2011).

\section{REFERENCES}

Alonso F., Temiño C. and Diéguez-Uribeondo J., 2000. Status of the white clawed crayfish, Austropotamobius pallipes (Lereboullet, 1858) in Spain: distribution and legislation. Bull. Fr. Pêche Piscic., 356, 31-54.

Anastácio P.M., Parente V.S. and Correia A.M., 2005. Crayfish effects on seeds and seedlings: identification and quantification of damage. Freshwater Biol., 50, 697-704.

Banha F. and Anastácio P.M., 2012. Waterbird-mediated passive dispersal of river shrimp Athyaephyra desmaresti. Hydrobiologia, 694, 197-204.

Bernardo J.M., Bruxelas S., Bochechas J. and Costa A.M., 2001. Freshwater crayfish in Portugal: a new Astacidae, Pacifastacus leniusculus (Dana), and less perspectives for the rehabilitation of the native Austropotamobius pallipes, Actas do $2^{\circ}$ Congresso Nacional de Conservação da Natureza, CD edition, Instituto de Conservação da Natureza, Lisboa, 1-6.

Correia A.M. and Ferreira Ó., 1995. Burrowing behavior of the introduced red swamp crayfish Procambarus clarkii (Decapoda:Cambaridae) in Portugal. J. Crustacean Biol., 15, 248-257.

Cruz M.J. and Rebelo R., 2007. Colonization of freshwater habitats by an introduced crayfish, Procambarus clarkii, in Southwest Iberian Peninsula. Hydrobiologia, 575, 191-201.

Cruz M.J., Segurado P., Sousa M. and Rebelo R., 2008. Collapse of the amphibian community of the Paul do Boquilobo Natural Reserve (central Portugal) after the arrival of the exotic American crayfish Procambarus clarkii. Herpetol. J., 18, 197-204.

Diéguez-Uribeondo J., 2006. The dispersion of the Aphanomyces astaci-carrier Pacifastacus leniusculus by humans represents the main cause of disappearance of the indigenous crayfish Austropotamobius pallipes in Navarra. Bull. Fr. Pêche Piscic., 380-381, 1303-1312.

Diéguez-Uribeondo J., Temiño C. and Múzquiz J.C., 1997. The crayfish plague fungus, Aphanomyces astaci in Spain. Bull. Fr. Pêche Piscic., 347, 753-763.

Geiger W., Alcorlo P., Baltanas A. and Montes C., 2005. Impact of an introduced crustacean on the trophic webs of Mediterranean wetlands. Biological Invasions, 7, 49-73.

Guan R.Z. and Wiles P.R., 1997. Ecological impacts of introduced crayfish on benthic fishes in a British lowland river. Conserv. Biol., 11, 641-647.

Hobbs H., Jass J. and Huner J., 1989. A review of global crayfish introductions with particular emphasis on two North American species. Crustaceana, 56, 299-316.

Holdich D.M., Reynolds J.D., Souty-Grosset C., and Sibley P.J., 2009. A review of the ever increasing threat to European crayfish from non-indigenous crayfish species. Knowl. Managt. Aquatic Ecosyst., 394-395, 11.

Lodge D.M., Stein R.A., Brown K.M., Covich A.P., Brönmark C., Garvey J.E. and Klosiewski S.P., 1998. Predicting impact of freshwater exotic species on native biodiversity: challenges in spatial scaling. Aust. J. Ecol., 23, 53-67. 
Lodge D.M., Taylor C.A., Holdrich D.M. and Skurdal J., 2000. Nonindigenous crayfishes threaten North American freshwater biodiversity: lessons from Europe. Fisheries, 25, 7-20.

Ninyerola M., Pons X. and Roure J.M., 2005. Atlas Climático Digital de la Península lbérica. Metodología y aplicaciones en bioclimatología y geobotánica. Universidad Autónoma de Barcelona, Bellaterra.

Nyström P., 1999. Ecological impact of introduced and native crayfish on freshwater communities: European perspectives. Crayfish in Europe as Alien Species, 11, 63-85.

Nyström P., Svensson O., Vensson O., Lardner B., Brönmark C. and Granéli W., 2001. The influence of multiple predators on a littoral pond community. Ecology, 82, 1023-1039.

Pond C.M., 1975. The role of the 'walking legs' in aquatic and terrestrial locomotion of the crayfish Austropotamobius pallipes (Lereboullet). J. Exp. Biol., 62, 447-454.

Rachalewski M., Banha F., Grabowski M. and Anastácio P.M., 2013. Ectozoochory as a possible vector enhancing the spread of an alien amphipod Crangonyx pseudogracilis. Hydrobiologia, 1-9.

Ramalho R., 2012. Dispersal and population regulation of the red swamp crayfish (Procambarus clarkii). Phd. Thesis. University of Évora, Portugal.

Ramos M.A. and Pereira T.M., 1981. Um novo Astacidae para a fauna portuguesa: Procambarus clarkii (Girard, 1852). Boletim Instituto Nacional Investigação e Pescas, 6, 37-47.

Souty-Grosset C., Holdich D.M., Noël P.Y., Reynolds J.D. and Haffner P. (eds.), 2006. Atlas of Crayfish in Europe, Muséum national d'Histoire naturelle, Paris, Patrimoines nature/s, 64, $187 \mathrm{p}$.

Taylor C.A., 2000. Systematic studies of the Orconectes juvenilis complex (Decapoda: Cambaridae), with descriptions of two new species. J Crustac. Biol., 20, 132-152.

Westman K., Savolainen R. and Julkunen M., 2002. Replacement of the native crayfish Astacus astacus by the introduced species Pacifastacus leniusculus in a small, enclosed Finnish lake: a 30-year study. Ecography, 25, 53-73. 